\title{
Successors' Characteristics, Preparation, Innovation, and Firm Performance: Taiwan and Japan
}

\author{
Jeng Liu ${ }^{1}$ \\ ${ }^{1}$ Professor, Department of Sociology, Dean, College of Social Sciences, Tunghai University, Taiwan, Province of \\ China \\ Correspondence: Jeng Liu, Professor, Department of Sociology, Dean, College of Social Sciences, Tunghai \\ University, Taiwan, Province of China.
}

Received: June 27, 2018

Accepted: July 24, $2018 \quad$ Online Published: August 10, 2018

doi:10.5539/ibr.v11n9p1

URL: https://doi.org/10.5539/ibr.v11n9p1

\begin{abstract}
Recent research has revisited business succession. Although important issues have been discussed from time to time, no consensus on any particular pattern of succession has emerged. Lacking a body of empirical findings to draw upon, discussions of business succession are often based on limited qualitative case studies and findings vary widely among researchers. In this research, we focus on both theoretical explanations and data promotion, and draw the following conclusions.

First, there are some differences in the corporate culture and business philosophy between Taiwanese and Japanese enterprises, and the training of successors is also different. Second, the number of female successors has been increasing in both Taiwan and Japan, while in Taiwan female successors have become even more open and innovative than their male counterparts. Third, successors in Taiwan and Japan make various kinds of preparations. The successors are expected to start from the front-line to win the loyalty of employees and managers, to keep in touch with front-line employees, to learn the enterprise's operating mode, and to think about a future development strategy. Fourth, the grown-up environment of the successor also plays an important role and has a great influence on the successor. Last, but not least, many well-known disputes have occurred in the enterprise succession process both in Taiwan and Japan, and the support provided by the previous generation and the "veterans" will make the succession process go smoothly.
\end{abstract}

Keywords: business succession, corporate philosophy, preparation and innovation, firm performance

\section{Introduction and the Significance of this Study}

Many scholars have devoted much effort over a long period of time to explore how Taiwanese corporations have used social connection networks based on unique Chinese-style sentimentality to expand their businesses and acquire a position in the global market. In recent years, as first generation business owners have gradually passed away or retired, succession arrangements have become crucial topics for sustainable corporate development, and have become a focus of attention in society as a whole. However, the issues related to business succession and inheritance have not received much attention from sociologists.

According to data released by China Credit Information Service Ltd.[CCIS] (2013), the managers of Taiwan's top one hundred groups are aging seriously: $63 \%$ of them are in their sixties, and $20 \%$ are in their seventies. These aging group corporations hold over NT $\$ 41$ trillion in assets (or 3 times the annual gross domestic product of Taiwan). If these groups are unable to complete their succession smoothly, serious damage to the Taiwan economy may result. Group corporations are facing a succession problem, and small and medium enterprises (SMEs), which have played an important role in creating the "economic miracle" in Taiwan, are also struggling to achieve a smooth succession. Furthermore, about $80 \%$ of Taiwanese people work in SMEs. The effects of this succession problem on the overall economic growth and social stability in Taiwan cannot be overlooked. Therefore, from an academic perspective, corporate succession and inheritance is not only an issue for business administration and management, but is also an important social fact that merits closer investigation.

In order to clearly grasp the characteristics demonstrated by Taiwanese corporations when faced with the issue of succession, this study will employ several analytical dimensions, including a firm's corporate scale, corporate compositional structure type, succession stage, and successor gender for an in-depth comparative analysis. 
Another focus is the succession pattern of family businesses and non-family businesses. Compared to succession at non-family businesses, whether family businesses can smoothly complete the work of succession and inheritance involves many non-organizational management dimensions, including the attitudes and views of the founders and their successors of different generations, resource distribution and transfer to family members, possible emotions and conflicts of interest, and the joint governance and balance of power between a successor and older employees and professional managers. This goes beyond what can be explained by successor training plans that focus on professional managers and, as a result, has elicited a great deal of curiosity and discussion from scholars. For instance, Benson's (1984) discussion of family business succession has become an important reference, and many other Western scholars have analyzed the topic of succession in family businesses (Birley, 1986; Donckel \& Frohlich, 1991; Handler, 1994).

While contemporary studies of corporate operations tend to stress "manager capitalism" with a separation of management rights and ownership rights, in the Chinese world, family businesses are still the mainstream among corporations (Lee, 2007; Wang \& Wen, 2011). According to statistics compiled by Tsai (2013), more than 70\% of Taiwanese corporations are family businesses, which on average have been established for around 30 years, and the average age of business owners is 59.6 years; meaning that the time for succession and corporate transformation is imminent. Current Taiwanese studies on the issue of business succession also tend to focus on family businesses (Wu \& Lien, 2012).

Furthermore, 34\% of Taiwanese family businesses have already experienced the first instance of succession. Many corporations are preparing to enter the third- or even fourth-generation succession stage, and they will face different succession procedures and difficulties. Therefore, it is necessary to focus on the differences in succession models at different succession stages, for this will help us better understand the features and forms of Taiwanese business succession. There has already been a certain level of research in the West in this regard, and this topic has become increasingly popular in recent years (Behn et al., 2006; Chua et al., 1999; 2003; Donckels \& Frohlich, 1991; Memili et al., 2011; Zahra et al., 2004). Therefore, this study will include both family businesses and non-family businesses, in the hope that a comparison between the two can help us establish an overall understanding of business succession models. As a result, we may be able to better understand organizational changes in the transition to systematic governance by Taiwanese corporations, particularly in terms of talent training, and, in turn, develop a localized theory related to Taiwanese business succession.

In short, we attempt to answer the following questions in this study: (1) How do corporations choose successors? What did the successors do to prepare for their positions? (2) Which support networks and resources will help corporate successors ensure a smooth transition? (3) Have there been any changes and what role are women playing in regard to positions of power in business succession? (4) What are the relationships among successors' characteristics, innovation, and firm performance? (5) For the issues mentioned above, are there any similarities and differences between Taiwanese and Japanese firms?

To clarify the above issues is both important and meaningful. In so doing, we will achieve a better understanding of successors' characteristics, preparation, the succession process, a firm's innovation, and performance. In the following sections of this paper, I first introduce the theoretical background and provide a literature review. I then describe the data and empirically estimate the effects of key variables on business succession. Given these efforts, I believe that this study will contribute to the accumulation of academic knowledge and policy development in this field.

\section{Theoretical Background and Literature Review}

\subsection{Business Succession in Taiwan}

Compared to the longstanding investigation in the Western academic world into business succession and inheritance (Beckhard \& Dyer, 1983; Behn et al., 2006; Benson, 1984; Birley, 1986; Dalton \& Kesner, 1983; Handler, 1994; Herrmann \& Datta, 2002; Wiersema, 1992), Taiwanese research work that has focused on the issue of business succession has been limited. Over the last 5 years, only 6 journal articles, one doctoral dissertation, and 43 master's theses have been related to business succession, and most of these have been in the field of management. Apparently, in the field of business succession and inheritance, there is still much room for sociological studies.

After reviewing existing studies on business succession (Chung \& Lin, 2009; Deng \& Wei, 2010; Hsu, 2011; Liu \& Lu, 2011; Wu \& Lien, 2012), we find that most studies have focused on family businesses. According to the survey report of listed companies by the CCIS (2013), 74\% of listed companies in Taiwan are family businesses. More importantly, over $37 \%$ of family businesses have been established for more than 30 years, and the business owners are on average 59.6 years old. In fact, they are entering the crucial business succession stage and the 
manufacturing industry that is facing the biggest challenge. However, in terms of the survey results, 58\% of Taiwanese family businesses have still not made arrangements for succession, with the succession problems being the most severe in the information and technology industry. Since the value of family businesses in Taiwan comprises $64 \%$ of the total value in Taiwan, if business succession cannot proceed smoothly, it will have a great effect on the growth and development of the Taiwanese economy.

Previous research related to business succession basically focused on two axes. The first axis involves the exploration of factors affecting the succession process of family businesses (Chung \& Lin, 2009; Liu \& Lu, 2011; Yu et. al, 2009), including differences in succession views between generations, the transfer of implicit knowledge and interpersonal resources, and relationships between successors, their families, and older employees. The second axis consists of the relationships among succession, corporate reform, and innovation (Chen, 2001; Wu \& Lien, 2012; Yeh \& Tsao, 1996), including the effect of business successor's characteristics, corporate innovation and operational performance, and succession and reform in corporate operational strategies.

Within the existing literature, researchers generally undertake research on single or several cases to organize and depict the process of family business succession in Taiwan, and attempt to use the perspective of organizational reform to explain the continuation of and changes in family businesses in the inheritance process, including family values and corporate culture, relationships, and resource networks (Guan et al., 2012; Lee, 2011). However, due to the research scale and selection of individual cases, such studies are generally focused on the discussion of business succession from the founders to their second generations, and on individual succession model research on family group corporations or SMEs. As these studies contain less discussion on changes in succession processes and models for corporations of different scales and generations, there is a lack of a systematic summary and comparative analysis.

Yu et al. (2009) have thus pointed out that corporate successors of different generations differ in terms of succession processes and values. As for the career choices of successors, some successors have placed emphasis on the effects of external environmental factors, while others have laid emphasis on family decisions. For views regarding family businesses, some successors have appreciated the hard work of their parents' generation, while others look to the repayment to society. For views regarding the next generation, some successors have focused on their responsibility for the family business, while other successors have made the choice to have a happy and balanced life.

From these case studies of succession and inheritance in corporations of different scales, we have also learned that such firms have significantly different planning and arrangements for succession (Lee, 2007). Most business owners have succession plans, plan to pass their businesses on to their children, and rarely consider professional managers as successors. Succession planning by current business owners focuses on the transmission of experience and the continuation of interpersonal relationships. Generally speaking, successors of small- and medium-sized family businesses generally obtain corporate knowledge and techniques externally. However, since the founders generally used the trial and error process to obtain corporate operational knowledge and technology, they use their own experiences as the basis of judgment, resulting in considerable difficulty in the inheritance of knowledge and technology (Hsu, 2011).

In terms of the selection of successors, although group corporations still focus on kinship, in-law members of the family can also become candidates for succession (Chung \& Lin, 2009). Successors of family group corporations have a broader knowledge base, as compared to successors of SMEs. Family group business successors have two ways in which to learn. The first is learning within family business groups, including direct instruction modes from their fathers, older employees, and elder siblings, as well as training within the company. The second is to acquire operational techniques and knowledge through working in foreign companies, or their own entrepreneurial activities, and by accumulating their own personal relationships. It is worth noting that, as the number of family members increases, including those who marry into group corporations, the selection and arrangement of successors becomes more difficult and complicated.

Without establishing a systematic succession mechanism, succession in family group corporations tends to fail, and results in fights over assets due to complex and inharmonious family relationships. As stated by Chung \& Lin(2009), succession in different generations and on different corporate scales gives rise to different challenges and problems that must be resolved, including equity distribution, the selection of a successor, and the inheritance of the family entrepreneurial spirit, all of which require different succession plans.

Because of this, existing research work cannot give us a holistic and systematic understanding of business succession. Our study will therefore collect information on the conditions of corporate managers, and provide an overview of corporations, corporate inheritance plans, the career formation of successors, the psychological 
preparation of successors, assistance received from the previous generation upon succession, support from family, support from the company's operational team, and local support.

\subsection{The Role and Position of Women in Business Succession Process}

Regarding the issue of business succession, few researchers have focused on gender. In fact, gender not only affects the differences in succession opportunities, but may also affect different acquisitions of family resources. Traditionally, enterprise founders have preferred to designate their sons, particularly eldest sons, as successors, unless all men who could have inherited had passed away, before women were chosen to serve as successors. This is related to the prevalent Chinese belief that a daughter will get married and become part of someone else's family (Kao, 1999). Koh (2013) also found differences in the gender ratios of business successors of different generations. In particular, among the second generation, there has been a great increase in the ratio of women as corporate leaders, and it has become closer to the ratio of men. However, after the third and fourth generations, the ratio of female leaders has decreased again. More studies are needed to understand the reasons for the change in the ratio of female corporate leaders.

According to a survey by the CCIS (2013), $14.06 \%$ of directors and supervisors of listed companies in Taiwan are women, even though the survey pointed out that the extent to which Taiwanese female directors are involved in decision-making is small. Chung \& Lin's (2009) discussion raised the issue as to whether second generation succession competitors "have the same mother," and implicitly showed the real influence of women in the corporate succession process. Chung and Lin (2009) further pointed out that whether family members have the same mother or not will affect the succession resources that they can control. One case study indicated that, when the second generation is made up of children from the first wife, there are smaller differences in succession resources held by the children. By contrast, if they are children from the second wife, there are greater differences in the succession resources held by the children.

In family businesses, women may be limited by the traditional view that "daughters will end up in other people's families," and be excluded from successors. However, when women become members of other family businesses through marriage, particularly when they become the mother of a successor candidate, the powers and resources of succession may be affected. Evidently, we should engage in a more nuanced discussion of the roles played by women, as well as the changes in their power positions in the process of business succession.

Kao's (1999) long-term observations on the development of SMEs in Taiwan focused on how wives of business owners participated in their family businesses, and explored their roles in the context of the family economy. Kao (1999) found that, while many wives of business owners did not have official titles, they were the best partners of their husbands (as executive officiers of the companies), helping their husbands with their work, sometimes providing recommendations, and pointing out blind spots in operations. It is absolutely necessary to include the gender factor in our analyses on business succession.

\subsection{The Framework of Research on Business Succession}

Recent research on business mainly refers to succession planning as theoretical background as developed by western scholars (e.g., Barnes \& Hershon, 1976; Behn et al., 2006; Birley, 1986; Chua et al., 2003; Herrmann \& Datta, 2002; Zahra et al., 2004). However, Chen (2011) argued that Western business succession planning studies primarily focus on the axis of professional managers, and ignore the successor's characteristics, economic and social backgrounds, and the firm's culture.

For example, Ka (1993) studied the apparel industry of Wufenpu in Taipei, Taiwan, and found that the restructuring of interpersonal networks caused by splitting family assets or entrepreneurship by family members would result in corporations facing competition and conflicts over limited organizational resources. This perspective of social networks can help us understand resource transfers and possible limitations in the succession process by providing a more nuanced angle of observation. In addition, Cosh et al. (2012) provided a detailed discussion on whether family businesses can use internal and external knowledge sources to elevate corporate innovative performance, which can also serve as a theoretical reference for our study to understand how business owners and successors use different sources of knowledge to create beneficial succession conditions.

In this study, we plan to employ Chen's (2007) 5P's analytical framework in our investigation. Differing from the Western perspective of human resources management, Chen (2007) divided corporate succession into five dimensions, including the people involved, the project and planning of succession, the succession process, succession progress, and performance (shown in Figure 1). 


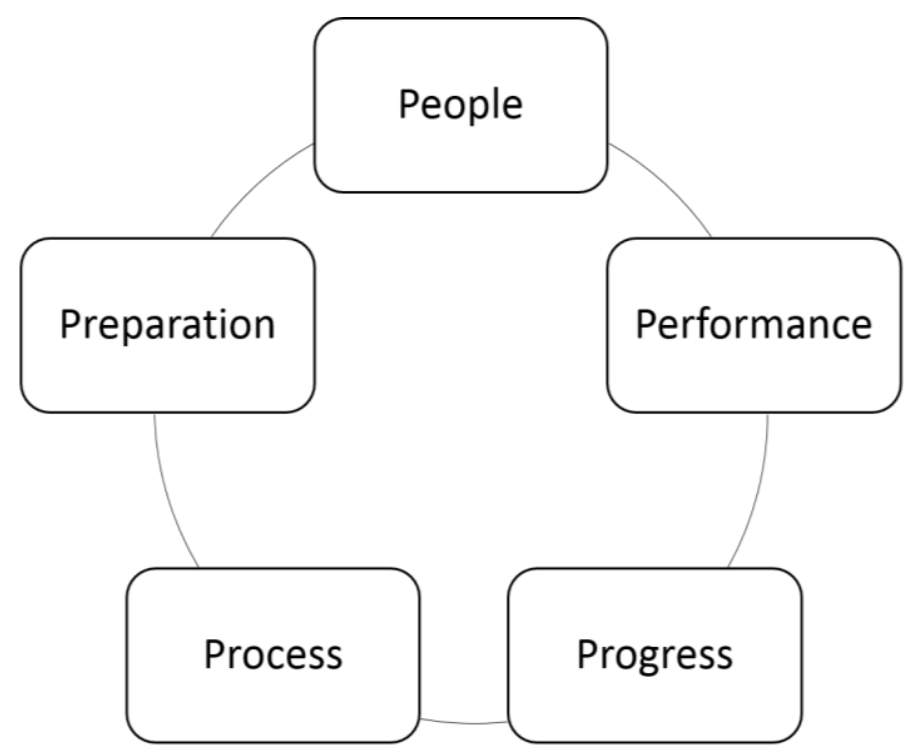

Figure 1. The 5 P's Analytical Framework (Chen, 2007)

This so-called "5P" analysis includes various issues involved in current business succession and inheritance research, which include succession attitudes of founders and successors, the selection and training of successor candidates, timing arrangements of succession, the problems faced in the handling of succession and inheritance, challenges faced by successors and resources needed, key roles that promote succession, and key factors in successful inheritance. Through this analytical framework, we will gain a more complete and comprehensive understanding of business succession.

\section{Data, Research Methods, and the Process of Transnational Cooperation}

Our data were collected in 2012-2013. The USA, UK, Australia, New Zealand, Japan, and Taiwan participated in this project. The workshop was held in Kyoto, at Doshisha University in December 2013. The key elements of the questionnaire design included: (1) general background of the company representative (including gender, age, education, number of generations, etc.); (2) basic data and operating status of the corporation (including the date of establishment, business type, family business or not, number of employees, business volume, core business philosophy, etc.); (3) business succession and inheritance plan (including inheritance plan, arrangements, and the requirements of the successor, etc.); (4) the career development of an enterprise's founders and previous successors (including entrepreneurial reasons, work experience, preparation for succession, etc.); (5) psychological preparation for succession (including reasons for succession, personal choice, and influence of the elders, etc.); (6) support of the former company president with respect to the succession (including how to form a new team, the support of family members and "veterans", assistance of local people or possible partners, etc.); and (7) status of enterprise reformation and innovation (including products, technology, distribution system, service, and delivery, etc.).

For the case of Taiwan, we obtained data on manufacturing enterprises from the Commerce Division of the Ministry of Economic Affairs through random sampling and generated 2,167 observations. We noted that $70.3 \%$ of Taiwanese manufacturing firms were owned and operated by families.

For the case of Japan, the Institute for Technology, Enterprise, and Competitiveness (ITEC) Center of Doshisha University was responsible for the survey of the local manufacturing industry in Kyoto. 903 observations were obtained on Japanese enterprise succession and inheritance. We noted that $76.1 \%$ of Japanese manufacturing enterprises were family-run.

\section{Empirical Results}

\subsection{Generation, Establishment Size, and Descriptive Statistics}

As shown in Table $1,60.3 \%(21.6+13.1+25.6=60.3)$ of Kyoto enterprises have been in existence for three or more generations. In fact, there are many century-old enterprises in Kyoto. However, only about one third $(32.6 \%)$ of enterprises in Taiwan have existed for two generations, and even a smaller number $(2.8 \%=2.6 \%+$ $0.2 \%$ ) for three or more generations, making them quite different from Kyoto's enterprises.

Taiwanese and Japanese enterprises are mainly small- and medium-sized enterprises. Taiwanese firms are larger 
than Japanese firms. Close to $20 \%(10.8+5.5+3.4=19.7)$ of Taiwanese firms have 50 or more workers, while only $13 \%$ of Japanese firms do. Some $28.6 \%$ of Japanese firms have only 5 or fewer workers while the corresponding figure for Taiwanese firms is only $13.5 \%$.

Table 1. Distribution of Generations and Establishment Size

\begin{tabular}{ccc}
\hline Generation & Taiwan & Japan \\
\hline $1^{\text {st }}$ & $1395(64.5 \%)$ & $132(15.3 \%)$ \\
$2^{\text {nd }}$ & $705(32.6 \%)$ & $208(24.2 \%)$ \\
$3^{\text {rd }}$ & $57(2.6 \%)$ & $186(21.6 \%)$ \\
$4^{\text {th }}$ & $1(0.0 \%)$ & $113(13.1 \%)$ \\
$5^{\text {th }}$ or above & $4(0.2 \%)$ & $220(25.6 \%)$ \\
\hline & & Japan \\
\hline Number of employees & Taiwan & $271(28.6 \%)$ \\
\hline Less than 5 & $290(13.5 \%)$ & $168(17.7 \%)$ \\
$5-9$ & $449(21 \%)$ & $153(16.1 \%)$ \\
$10-19$ & $564(26.3 \%)$ & $186(19.6 \%)$ \\
$20-49$ & $418(19.5 \%)$ & $57(6 \%)$ \\
$50-99$ & $231(10.8 \%)$ & $57(6 \%)$ \\
$100-249$ & $117(5.5 \%)$ & $9(0.9 \%)$ \\
\hline
\end{tabular}

From Table 2, we learn that Japanese descendants are more likely to take over the firms from their parents than are Taiwanese descendants (2.44 vs. 1.82). However, Taiwanese successors are more likely to start new businesses than Japanese successors (2.82 vs. 2.52). Only $4 \%(1-0.96=0.04)$ of Japanese successors are female, while $16 \%(1-0.84=0.16)$ of Taiwanese successors are female. Japanese successors are older (59.11 vs. 49.13), and with higher education (3.23 vs. 2.90 , where 1 refers to junior high school or lower, 2 refers to senior high school, 3 refers to vocational school or college, 4 refers to university, and 5 refers to graduate school or higher). Furthermore, Japanese successors are more stable than Taiwanese successors (5.40 vs. 3.18).

Table 2. Descriptive Statistics of Key Variables

\begin{tabular}{lcc}
\hline & Taiwan & Japan \\
\hline Intention of Succession & 1.82 & 2.44 \\
Willingness to Start a New Business & 2.82 & 2.52 \\
Amount of Benefit & 2.23 & 1.73 \\
Age of Successor & 49.13 & 59.11 \\
Male & 0.84 & 0.96 \\
Generation & 2.08 & 3.50 \\
Distance b/w home and the firm & 2.28 & 2.23 \\
Education & 2.90 & 3.23 \\
Stability & 3.18 & 5.40 \\
\hline
\end{tabular}

\subsection{Corporate Philosophy and the Preparation of Successors}

Compared with Taiwanese enterprises, Japanese corporations attach greater significance to the family motto, business brand, and philosophy. During the last several decades, many Japanese enterprises, like Sony, Toshiba, Toyota Motor, etc. have been trustworthy big brands and the major choices of customers. Moreover, they have mastered the core technology while other manufacturers only cooperate in manufacturing. It can be seen from items produced by Taiwanese enterprises that they also pay close attention to philosophy and brand, but they can only reform other aspects since they have not mastered the core technology as the Japanese have. From another perspective, Japan is more conservative than Taiwan in enterprise thinking, as they will not introduce reforms or innovate without careful consideration in order to maintain their goodwill (brand name) and avoid shaking the mentality of consumers.

Table 3. Consideration of Corporate Philosophy, Goodwill, and other Items

\begin{tabular}{lcc}
\hline & Protected / Not Changed & \\
\hline & Taiwan & Japan \\
\cline { 2 - 3 } Corporate philosophy (Family motto) & $54.3 \%$ & $72.6 \%$ \\
Goodwill (Trade name, Brand name) & $45.7 \%$ & $78.8 \%$ \\
Production Techniques & $19.3 \%$ & $34.5 \%$ \\
Sales System & $19.5 \%$ & $31.3 \%$ \\
Sales Area & $17.6 \%$ & $25.9 \%$ \\
Customers & $11.1 \%$ & $19.7 \%$ \\
Suppliers & $18.2 \%$ & $24.4 \%$ \\
Product and Service Content & $19.5 \%$ & $28.4 \%$ \\
Business Content & $32.7 \%$ & $40.5 \%$ \\
\hline
\end{tabular}


Taiwanese entrepreneurs are more flexible in their thinking, and females are more innovative. One example is Cher Wang who created the globally-known HTC mobile phone brand. Japanese entrepreneurs exhibit near consistency in Table 4 as both male and female successors have tried very hard to maintain the corporate philosophy and goodwill, while female successors are even more conservative than male successors. This might be the result of Japan's social context, where there are few female entrepreneurs and their task is to maintain the family motto and brand name instead of making too much change once they become the leader of the corporation. In the formation process of Japanese society, females are prone to obey their elders, which may influence their performance in enterprise thinking as well.

Table 4. Corporate Philosophy, Preparation before Succession, and Gender

Protected / Not Changed Corporate Philosophy Protected / Not Changed Goodwill

Communication with the employees in general

Communication with the executives

\begin{tabular}{cccc}
\multicolumn{2}{c}{ Taiwan } & \multicolumn{2}{c}{ Japan } \\
\hline Male & Female & Male & Female \\
\hline $55.4 \%$ & $44.5 \%$ & $72.3 \%$ & $79.1 \%$ \\
$47.4 \%$ & $32.4 \%$ & $78.6 \%$ & $88.6 \%$ \\
$65.6 \%$ & $57.9 \%$ & $35.1 \%$ & $39.1 \%$ \\
$64.9 \%$ & $50.0 \%$ & $15.2 \%$ & $19.6 \%$
\end{tabular}

Successors in Taiwan will make preparations in every respect and establish close contact with enterprise executives and front-line employees so as to obtain internal support after succession. They will also work on the front-line to maintain contact with consumers and gain more experience so as to form better and more rational operating strategies. With respect to the gender of the successor, there is a great difference between male and female successors in Taiwan, with female successors having less contact with employees and managers.

In Japan, a successor's priority training is also to work on the front-line and accumulate work experience, but there is little training in communication with executives and managers. We presume the reason might be that Japanese enterprises have basically been established for a very long time with great credibility and powerful brands. The managers are used to working together with the previous generation and are basically old friends or relatives of the successor. Therefore, the successors may follow the implementation and operating strategy of the previous generation since their task is to maintain the enterprise and pass it on to the next generation. On the whole, Taiwanese enterprises and Japanese enterprises both pay close attention to the successors' work experience, and the best way to cultivate them and enhance their capability is by having them work on the front-line.

\subsection{Innovation for Different Items and Corporate Performance}

We have also studied the influence of product, method, distribution system, service, and delivery innovations on corporate performance. For those Taiwanese firms that have done something in regard to product innovation, $6.4 \%$ have claimed that their performance is good, compared to other companies within the same industry; $79.4 \%$ that it is somewhat good; $13.3 \%$ somewhat bad; and $0.9 \%$ bad. By contrast, for Japanese firms the corresponding figures are $14.3 \%, 59.3 \%, 24.6 \%$, and $2.9 \%$, respectively. From these five aspects of innovation, the relationships between innovation items and performance exhibit very similar patterns for Taiwanese firms and Japanese firms.

Table 5. Innovation and Performance

\begin{tabular}{|c|c|c|c|c|c|}
\hline \multirow[b]{2}{*}{ Innovation } & & \multicolumn{4}{|c|}{ Performance, compared to other companies } \\
\hline & & Good & $\begin{array}{l}\text { Somewhat } \\
\text { Good }\end{array}$ & Somewhat Bad & Bad \\
\hline \multirow[t]{2}{*}{ Manufactured product } & Taiwan & $6.4 \%$ & $79.4 \%$ & $13.3 \%$ & $0.9 \%$ \\
\hline & Japan & $14.3 \%$ & $58.3 \%$ & $24.6 \%$ & $2.9 \%$ \\
\hline \multirow[t]{2}{*}{ Production method } & Taiwan & $6.3 \%$ & $79.2 \%$ & $13.0 \%$ & $1.4 \%$ \\
\hline & Japan & $15.1 \%$ & $59.5 \%$ & $22.7 \%$ & $2.6 \%$ \\
\hline \multirow{2}{*}{$\begin{array}{l}\text { Supply, storage, } \\
\text { distribution system }\end{array}$} & Taiwan & $5.5 \%$ & $79.1 \%$ & $13.9 \%$ & $1.4 \%$ \\
\hline & Japan & $15.1 \%$ & $56.8 \%$ & $24.0 \%$ & $4.1 \%$ \\
\hline \multirow[t]{2}{*}{ Service } & Taiwan & $6.4 \%$ & $78.7 \%$ & $14.0 \%$ & $0.9 \%$ \\
\hline & Japan & $16.4 \%$ & $55.7 \%$ & $23.8 \%$ & $4.0 \%$ \\
\hline \multirow[t]{2}{*}{ Delivery } & Taiwan & $6.0 \%$ & $78.8 \%$ & $13.8 \%$ & $1.4 \%$ \\
\hline & Japan & $13.2 \%$ & $56.1 \%$ & $25.5 \%$ & $5.2 \%$ \\
\hline
\end{tabular}

We can see that Taiwanese enterprises are more confident (or self-complacent) in themselves, as more than $80 \%$ of enterprises say they have good or somewhat good performance, while the percentage in Japan is around 70\%. Furthermore, only $15 \%$ of Taiwanese firms think their performance is relatively somewhat bad or bad, compared to other companies, while more than $25 \%$ of Japanese firms think their performance is somewhat bad or bad. 


\subsection{Regression of Successors' Intention to Succeed and Start New Business}

Table 6 demonstrates the effects of different variables on the descendants' intention to succeed and to start new business.

Table 6. Intention to Succeed and to Start New Business

\begin{tabular}{|c|c|c|c|c|}
\hline & \multicolumn{2}{|c|}{ Intention to Succeed to the Business } & \multicolumn{2}{|c|}{ Willingness to Start New Business } \\
\hline & Taiwan & Japan & Taiwan & Japan \\
\hline \multirow[t]{2}{*}{ Male $($ Reference $=$ female $)$} & -0.031 & $0.546^{*}$ & $-0.197^{*}$ & 0.167 \\
\hline & $(0.079)$ & $(0.148)$ & $(0.073)$ & $(0.154)$ \\
\hline \multirow[t]{2}{*}{ Generation } & -0.008 & -0.046 & -0.188 & $-0.096^{*}$ \\
\hline & $(0.061)$ & $(0.062)$ & $(0.111)$ & $(0.028)$ \\
\hline \multirow[t]{2}{*}{ Family-run business } & -0.230 & $0.290^{*}$ & 0.095 & -0.105 \\
\hline & $(0.134)$ & $(0.090)$ & $(0.124)$ & $(0.097)$ \\
\hline \multirow[t]{2}{*}{ Distance $\mathrm{b} / \mathrm{w}$ home and the firm } & $0.407^{*}$ & $0.167^{*}$ & -0.059 & -0.057 \\
\hline & $(0.041)$ & $(0.036)$ & $(0.040)$ & $(0.039)$ \\
\hline \multirow[t]{2}{*}{ Firm size } & $-0.090^{*}$ & 0.078 & $-0.102^{*}$ & 0.044 \\
\hline & $(0.043)$ & $(0.047)$ & $(0.040)$ & $(0.051)$ \\
\hline \multirow{2}{*}{$\begin{array}{l}\text { Senior high school (Reference }= \\
\text { Junior high school or lower) }\end{array}$} & $-0.839^{*}$ & -0.092 & 0.295 & 0.151 \\
\hline & $(0.170)$ & $(0.168)$ & $(0.166)$ & $(0.188)$ \\
\hline \multirow[t]{2}{*}{ Vocational school or College } & $-1.323^{*}$ & 0.285 & $0.381^{*}$ & -0.022 \\
\hline & $(0.162)$ & $(0.301)$ & $(0.159)$ & $(0.212)$ \\
\hline \multirow[t]{2}{*}{ University } & $-1.041^{*}$ & 0.072 & 0.278 & 0.153 \\
\hline & $(0.148)$ & $(0.075)$ & $(0.147)$ & $(0.080)$ \\
\hline \multirow[t]{2}{*}{ Graduate school or higher } & $-0.861^{*}$ & -0.084 & 0.003 & 0.287 \\
\hline & $(0.157)$ & $(0.185)$ & $(0.155)$ & $(0.199)$ \\
\hline Constant & $2.258^{*}$ & $1.749^{*}$ & $3.369^{*}$ & $2.904^{*}$ \\
\hline $\mathrm{R}^{2}$ & 0.22 & 0.091 & 0.059 & 0.037 \\
\hline
\end{tabular}

Note. $*$ indicates $\mathrm{p}<0.05$; standard errors are in parentheses.

In Japan, males have a stronger intention to be successors than females, while this gender effect is not statistically significant in regard to their willingness to start new business. On the contrary, the effect of gender is not significant for Taiwanese successors, neither is the intention to take over the firm, nor to start new business.

Based on similar results in Taiwan and Japan, the distance between household location and enterprise location has a positive influence on a successor's intention to take over the enterprise, just as the Japanese saying states that "the child's impression of his father is always his back during working." Whether or not the enterprise's location is in a successor's birth/growing-up place will influence the successor's willingness to take over. If the enterprise's location is in one's birth/growing-up place, then a successor will be more likely to take over the firm.

Male entrepreneurs in Taiwan have less of an intention to create a new business, which is consistent with what is reflected in Table 4. They are more willing to maintain the corporate philosophy than female entrepreneurs in Taiwan. In other words, male Taiwanese entrepreneurs are more conservative and less willing to create new businesses, just like Japanese enterprise successors.

With respect to establishment size, the larger the Taiwanese establishment is, the less strong is the intention for the descendants to succeed, and the less likely it is that a new business will be created. By contrast, the effect of firm size on the descendants' intention to take over the firm and on the successors' willingness to create a new business are not statistically significant for Japanese firms.

With respect to educational background, many Taiwanese entrepreneurs are senior high school or vocational school graduates and are more prone to starting new businesses. In Japan, the successor's educational background does not influence her/his willingness to create a new business.

\subsection{Regression of Business Succession Process}

Differing from our expectations, after controlling for other variables, business generation, the successor's age, whether she/he became the mediator, and firm size do not have statistically significant effects on the succession process in either Taiwanese or Japanese firms. From Table 7, we learn that getting support from the predecessor and her/his executives are the key factors to ensure that the handover process is relatively smooth. 
Table 7. Smooth Handover during the Succession Process

\begin{tabular}{lcc}
\hline & Taiwan & Japan \\
\hline Generation & -0.420 & -0.055 \\
& $(0.242)$ & $0.036)$ \\
\hline Male & 0.188 & 0.365 \\
& $(0.182)$ & -0.001 \\
\hline Age & -0.014 & $(0.005)$ \\
\hline Became mediators & $(0.010)$ & 0.180 \\
& 0.114 & $(0.111)$ \\
\hline Had worked at other companies & $(0.214)$ & -0.067 \\
& -0.119 & $(0.078)$ \\
\hline Had already worked in the company & $(0.089)$ & -0.027 \\
& $(0.042)$ \\
\hline Apupport from last generation & $9.449 \mathrm{E}-5$ & $0.617 *$ \\
& $(0.002)$ & $(0.036)$ \\
\hline Firm Size & $0.237 *$ & $0.199 *$ \\
& $(0.085)$ & $(0.038)$ \\
\hline Constant & $0.284 *$ & -0.120 \\
\hline $\mathrm{R}^{2}$ & $(0.101)$ & $(0.062)$ \\
\hline Note & 0.057 & 0.757 \\
\hline
\end{tabular}

Note. $*$ indicates $\mathrm{p}<0.05 ;$ standard errors are in parentheses.

\subsection{Regression of Performance after Succession}

First of all, after controlling for other variables, the number of generations has a significant negative impact on performance after succession in both Taiwan and Japan. It indicates that the more generations there are since the enterprise was formed, the more challenges and interventions the successors may encounter.

Gender does not exhibit a significant effect on performance in either Taiwanese or Japanese firms. The effect of age on performance is negative for both Taiwanese and Japanese firms. To be specific, this effect is statistically significant for Taiwanese firms, but not significant for Japanese firms. It indicates that, for Taiwanese firms, the older the successor is, the poorer the firm's performance is.

Management innovation has a significantly positive impact on enterprise performance in both Taiwan and Japan. The greater the extent of management innovation, the better the performance of the firm after the succession takes place.

Table 8. Performance after Succession

\begin{tabular}{|c|c|c|}
\hline & Taiwan & Japan \\
\hline Generation & $\begin{array}{c}-0.128 * \\
(0.032)\end{array}$ & $\begin{array}{c}-0.041 * \\
(0.019)\end{array}$ \\
\hline Male & $\begin{array}{r}-0.002 \\
(0.044) \\
\end{array}$ & $\begin{array}{r}-0.236 \\
(0.126)\end{array}$ \\
\hline Age & $\begin{array}{c}-0.008 * \\
(0.002)\end{array}$ & $\begin{array}{l}-0.004 \\
(0.002)\end{array}$ \\
\hline Innovation on Management & $\begin{array}{l}0.084 * \\
(0.023)\end{array}$ & $\begin{array}{l}0.119 * \\
(0.035)\end{array}$ \\
\hline Innovation on Openness & $\begin{array}{l}0.083 * \\
(0.011)\end{array}$ & $\begin{array}{l}-0.045 \\
(0.028)\end{array}$ \\
\hline Innovation on Production & $\begin{array}{c}0.039 \\
(0.056)\end{array}$ & $\begin{array}{l}0.255 * \\
(0.065)\end{array}$ \\
\hline Innovation on Processing & $\begin{array}{l}0.201 * \\
(0.063)\end{array}$ & $\begin{array}{r}-0.058 \\
(0.069)\end{array}$ \\
\hline Stability & $\begin{array}{c}0.014 \\
(0.015)\end{array}$ & $\begin{array}{c}-0.037 \\
(0.030)\end{array}$ \\
\hline Firm Size & $\begin{array}{l}0.128 * \\
(0.021)\end{array}$ & $\begin{array}{l}0.194 * \\
(0.041)\end{array}$ \\
\hline Constant & $2.095 *$ & $2.043 *$ \\
\hline $\mathrm{R}^{2}$ & 0.135 & 0.139 \\
\hline
\end{tabular}

Note. * indicates $\mathrm{p}<0.05 ;$ standard errors are in parentheses.

In Taiwan, open innovation and procedural innovation also have positive impacts on performance. In fact, these factors are to a certain degree likely to be interrelated with the successor's generation and age. A firm's long 
history and the successor's age may limit the degree of openness and procedural innovation development of the enterprise because older firms and older successors may have less momentum to make significant changes.

With respect to innovation and performance, on the one hand, innovation in relation to openness and service improve the performance of Taiwanese firms. On the other hand, product innovation has a positive impact on the performance after succession for Japanese firms. As is widely known, Japanese manufacturers are able to master core product technology and to devote themselves to product innovation. Therefore, when the successor takes over, the overall performance of the enterprise will be better if more is invested in product innovation.

\section{Discussion and Conclusion}

\subsection{Findings and Issues}

Although recent research work has revisited business succession, many important issues have not been investigated systematically. We believe that, by bringing the successor's characteristics and preparation back in, the relationships among the successor's efforts, innovation, and firm's performance can be analyzed more thoroughly.

According to our quantitative data analyses, some important findings are summarized as follows. First, there are some differences in corporate culture and business philosophy between Taiwanese and Japanese enterprises. Taiwanese firms tend to engage in innovation and reformation, while Japanese firms attach great significance to product innovation. These facts are also reflected in the different training of successors. Taiwanese enterprises believe that innovation and reformation can inject new vitality into the enterprise and open up new markets, whereas Japanese enterprises think that product technology improvements and new products can maintain enterprise brands and win loyal consumers.

Second, the influence of female successors has been increasing in the succession process. The number of female successors has increased in both Taiwan and Japan despite the fact that male successors still play a dominant role under the influence of a patriarchal society. We can see from the data that enterprises with female successors in Taiwan are more open and innovative than those with male successors.

Third, successors in Taiwan make preparations in various respects. According to enterprise thinking in Taiwan, it is very helpful for successors to get access to all things. Some enterprises want the successors to start from the front-line to win the loyalty of employees and managers, to keep in touch with front-line employees, to learn the enterprise's operating mode, and to think about a future development strategy. In Japan, a successor's priority training is also to work on the front-line and accumulate work experience. However, there is little training in communication with managers and broadening the scope of the enterprise's operations. Japanese enterprises pay close attention to credibility and brand, and the main task of their successors is to sustain the enterprise and pass it on to the next generation. The "veterans" of enterprises are basically old friends and relatives of the successor, and they do not have much communication.

Fourth, the environment where the successor grew up also plays an important role. If the enterprise is located where the successor lives, then her/his willingness to take over will increase, since he/she may have witnessed the hard work of the parents, learned about the enterprise's operations, and even received training from the enterprise. Such successors may not be interested in the enterprise business, but they are still willing to take over the enterprise established by their parents to maintain and develop the family business.

Last, but not least, the support of the previous generation and the "veterans" will make the succession process relatively smooth. Many well-known disputes have occurred in the enterprise succession process in Japan and Taiwan, and the previous generation and "veterans" play an important role in it, since the succession process will not be easy without their support.

\subsection{Suggestions for Future Research}

Our study contributes to a better understanding of a successor's characteristics, preparation, succession process, the firm's innovation, and firm performance. Our framework draws upon the 5P's analysis to enrich previous research on business succession. In addition, we enhance the rigor of our research findings by using data from Taiwan and Japan. Nonetheless, we reiterate that this study has focused on only limited issues related to business succession. There remains much scope for further investigation in future studies.

This study serves as a starting point for investigating business succession of manufacturing firms of Taiwan and Japan, and readers should bear in mind the following limitations. First, this study only investigated business succession of manufacturing firms. Similar studies on firms from other industries are needed to confirm the results found in this study. Second, future research might extend our analysis to other countries since we have 
only accessed data from Taiwan and Japan so far. Third, future research might build upon our analysis to consider better data, alternative measures, and more comprehensive models of succession processes. By continuing to investigate these topics, we can contribute to the accumulation of academic knowledge and policy development in this field more objectively and effectively.

\section{References}

Barnes, L. B., \& Hershon, S. A. (1976). Transferring power in the family business. Harvard Business Reviews, 54(4), 105-114.

Beckhard, R., \& Dyer, W. G. (1983). Managing continuity in the family-owned business. Organizational Dynamics, 12, 4-12. https://doi.org/10.1016/0090-2616(83)90022-0

Behn, B. K., Dawley, D. D., Riley, R., \& Yang, Y. (2006). Deaths of CEOs: Are delays in naming successors and insider/outsider succession associated with subsequent firm performance? Journal of Managerial Issues, 18, $32-46$.

Benson, B. (1984). The enigma of the family-owned business. Perspective, 10(1), 3-6.

Birley, S. (1986). Succession in the family firm: the inheritor's view. Journal of small business management, 32(3), 29-39.

CCIS (2013). 2012 Business Groups in Taiwan. Taipei, Taiwan: China Credit Information Service Ltd.

Chen, C. H. (2001). Bandi and Laoban: The Development of Elementary Organization Capability in Taiwan's enterprise. Taipei, Taiwan: Linking.

Chen, K. C. (2011). The Training Pattern for Family Enterprise Successors in Taiwan. In J. H. Wang \& C. T. Wen (Eds.), Does family business still matter? (pp. 153-187). Taipei, Taiwan: Chuliu Publisher.

Chen, M. Z. (2007). Who is the next one? Taipei, Taiwan: Jin Da Ding Press.

Chua, J. H., Chrisman, J. J., \& Sharma, P. (1999). Defining the family business by behavior. Entrepreneurship: Theory \& Practice, 23(4), 19-39. https://doi.org/10.1177/104225879902300402

Chua, J. H., Chrisman, J. J., \& Sharma, P. (2003). Succession and non-succession concerns of family firms and agency relationship with non-family managers. Family Business Review, 16(2), 89-107. https://doi.org/10.1111/j.1741-6248.2003.00089.x

Chung, H. M., \& Lin, C. H. (2009). The Relationship between Succession Resources and Role Embeddedness in Family Business Group: A Network Perspective. Organization and Management, 2(2), 155-195.

Cosh, A., Fu, X., \& Hughes, A. (2012). Organizational structure and innovation performance in different environments. Small Business Economics, 39(2), 301-317. https://doi.org/10.1007/s11187-010-9304-5

Dalton, D. R., \& Kesner, I. F. (1983). Inside/outside succession and organizational Size: The pragmatics of executive replacement. Academy of Management Journal, 26, 736-742.

Deng, J. B., \& Wei, M. J. (2010). Family Firms and Generational Change: Taiwanese Manufacturing Businesses in the Pearl River Delta. Mainland China Studies, 53(3), 25-51.

Donckels, R., \& Frohlich, E. (1991). Are family businesses really different? European experiences from stratus. Family Business Review, 4(2), 149-160. https://doi.org/10.1111/j.1741-6248.1991.00149.x

Guan, Y. R., Hsung, R. M., \& Lin, Y. J. (2012). Innovation Mechanisms in Taiwan IC Industry: The Case of the Patent-Based Inventor Networks in 2001 and 2005. Research Center for Humanities and Social Sciences, 24(1), 51-82.

Handler, W. C. (1994). Succession in family business: A review of the research. Family Business Review, 7(2), 133-157. https://doi.org/10.1111/j.1741-6248.1994.00133.x

Herrmann, P., \& Datta, D. K. (2002). CEO successor characteristics and the choice of foreign market entry mode: An empirical study. Journal of International Business Studies, 33, 551-569. https://doi.org/10.1057/palgrave.jibs.8491031

Hsu, Y. W. (2011). Succession and Intergenerational Relations of Century-Old Family Business in Taiwan. Journal of Adult and Lifelong Education, 16, 83-112.

Ka, C. M. (1993). Market, social networks, and the production organization of small-scale industry in Taiwan: the garment industries in Wufenpu. Taipei, Taiwan: Institute of Ethnology, Academia Sinica.

Kao, C. S. (1999). Economic Action and Social Signification of 'Entrepreneurial Bosses' Wives': Taiwanese 
Small-Medium Business. Taipei, Taiwan: Linking.

Koh, A. (2013). Current situation of Asian business families. In the 2nd Chinese Family Businesses Forum. Forum conducted at the GIS NTU Convention Center.

Lee, Z. R. (2007). Between the State Power and Chinese Familism: Corporate Control and Intercorporate Networks in Taiwan Revisited. Taiwanese Journal of Sociology, 13, 173-242.

Lee, Z. R. (2011). Determinants of Kinship Networks in Taiwanese Business Groups. Taiwanese Journal of Sociology, 46, 115-166.

Liu, D. C., \& Lu, S. H. (2011). The Succession Problems of Family-owned Business: A Case Study of a Lead-Acid Battery Company in Central Taiwan. Journal for SME Development, 22, 1-24.

Memili, E., Chrisman, J. J., \& Chua, J. H. (2011). Transaction costs and outsourcing decisions in small- and medium-sized family firms. Family Business Review, 24(1), 47-61. https://doi.org/10.1177/0894486510396706

Tsai, H. C. (2013). Chinese Family Enterprise 2012 Report. Forum of Taiwan Institute of Directors, 1, 19-25.

Wang, J. H. \& Wen, C. T. (2011). Does family business still matter? Taipei, Taiwan: Chuliu Publisher.

Wiersema, M. F. (1992). Strategic consequences of executive succession within diversified firms. Journal of Management Studies, 29, 73-94. https://doi.org/10.1111/j.1467-6486.1992.tb00653.x

Wu, C. M., \& Lien, Y. H. (2012). Research on the Process of Organizational Change, Conflict and Transformation Led by Family Business Succession. Journal of Management, 29(3), 279-305.

Yeh, K. S., \& Tsao, L. C. (1996). A Network Analysis of Ownership Succession in Family Owned Business. Journal of Management, 13(2), 197-225.

Yu, P. H., \& Lin, C. Y. Y., \& Chang, D. H. F. (2009). Succeed or Change: The Succession Process in Taiwanese Enterprises: A Qualitative Research. Organization and Management, 2(2), 109-153.

Zahra, S. A., Hayton, J. C., \& Salvato, C. (2004). Entrepreneurship in family vs. non-family firms: a resource-based analysis of the effect of organizational culture. Entrepreneurship: Theory \& Practice, 28(4), 363-38. https://doi.org/10.1111/j.1540-6520.2004.00051.x

\section{Copyrights}

Copyright for this article is retained by the author(s), with first publication rights granted to the journal.

This is an open-access article distributed under the terms and conditions of the Creative Commons Attribution license (http://creativecommons.org/licenses/by/4.0/). 